\section{DIGITAL COMMONS \\ @ UNIVERSITY OF SOUTH FLORIDA}

\section{ABO: Interactive Journal for Women in the Arts, 1640-1830}

Volume 11

Issue 1 Summer 2021

Article 16

2021

\title{
Absent Objects
}

Freya Purcell

$V \& A / R C A$, freya.purcell@network.rca.ac.uk

Follow this and additional works at: https://digitalcommons.usf.edu/abo

Part of the Dramatic Literature, Criticism and Theory Commons, Educational Methods Commons, Feminist, Gender, and Sexuality Studies Commons, and the Literature in English, British Isles Commons

\section{Recommended Citation}

Purcell, Freya (2021) "Absent Objects," ABO: Interactive Journal for Women in the Arts, 1640-1830: Vol.11: Iss.1, Article 16.

http://doi.org/10.5038/2157-7129.11.1.1257

Available at: https://digitalcommons.usf.edu/abo/vol11/iss1/16

This Conversation is brought to you for free and open access by Digital Commons @ University of South Florida. It has been accepted for inclusion in ABO: Interactive Journal for Women in the Arts, 1640-1830 by an authorized administrator of Digital Commons @ University of South Florida. For more information, please contact digitalcommons@usf.edu. 


\section{Absent Objects}

Abstract

Observations on studying during the Global Pandemic in the summer of 2020, access to archives.

Considering the relationship between physical objects and the digital world in studying Design History.

\section{Keywords}

design history, material history, Studies, dissertation, urban history

Creative Commons License

(c) (1) (9)

This work is licensed under a Creative Commons Attribution-Noncommercial 4.0 License 
The sound of rustling paper in an old archive. The thrill of handling an object, crafted by someone a lifetime ago whom I will never meet (all the while praying I don't drop it). These were the joys I was looking forward to while researching for my MA dissertation in the History of Design. Instead like researchers and students across the globe my summer of research would not be filled with new archives to explore. Instead, I would be sat firmly at my desk at my laptop.

Object analysis is a key part of the research methodology in design history. It is in the minute details of an object that a wider history can be revealed. The placement of a seam, the patterns of wear to an object, these are the kind of little details that can start a whole new line of discovery. Digitisation of objects can help in this analysis as it makes a far wider range of objects available but is not a perfect replacement. Details do not always show up in catalogue images such as how the object reflects light. Other times the angles of photos can be limited. It was intimidating therefore to think how I could plan my dissertation when I did not know when I might be able to see what I was studying in person.

For me, the answer to this challenge was to remove the option of in person object analysis entirely and choose to focus on a space and set of objects that no longer exists: the saloop stall. Serving the hot drink Saloop (a corruption of Arabic drink Sahlep), these street stalls were popular in London from the 1770s onwards yet have been largely unresearched. This is likely due to the fact that they primarily served to early morning labourers and individuals who were unlikely to leave a written record. In addition, the objects that made up the saloop stall, the tables, the style of tea urns used, do not survive and so rule out close object analysis. For me this was liberating and helped me clarify my approach. It took away the anxiety of whether amidst successive lockdowns I would actually be able to see objects or of worrying about whether my research would be strong enough if I was not able to. Instead, it forced me to be diverse in my use of sources and approach, utilizing a broad range of evidence such as prints and court cases.

Occupying the street in the late evening to early morning, these stalls provided a way into exploring the wider space of the city through design history. Though I could not handle any of the objects they allowed me to explore the daily lives of Londoners in the long eighteenth century. It provided insight into simple daily routines and social spaces of the market gardeners and coach divers of London; places where people grabbed breakfast on their way to work or stopped off after an evening out on the town. Spaces, that at this moment from my desk working at my laptop seem worlds away. 
ABO: Interactive Journal for Women in the Arts, 1640-1830, Vol. 11 [2021], Iss. 1, Art. 16

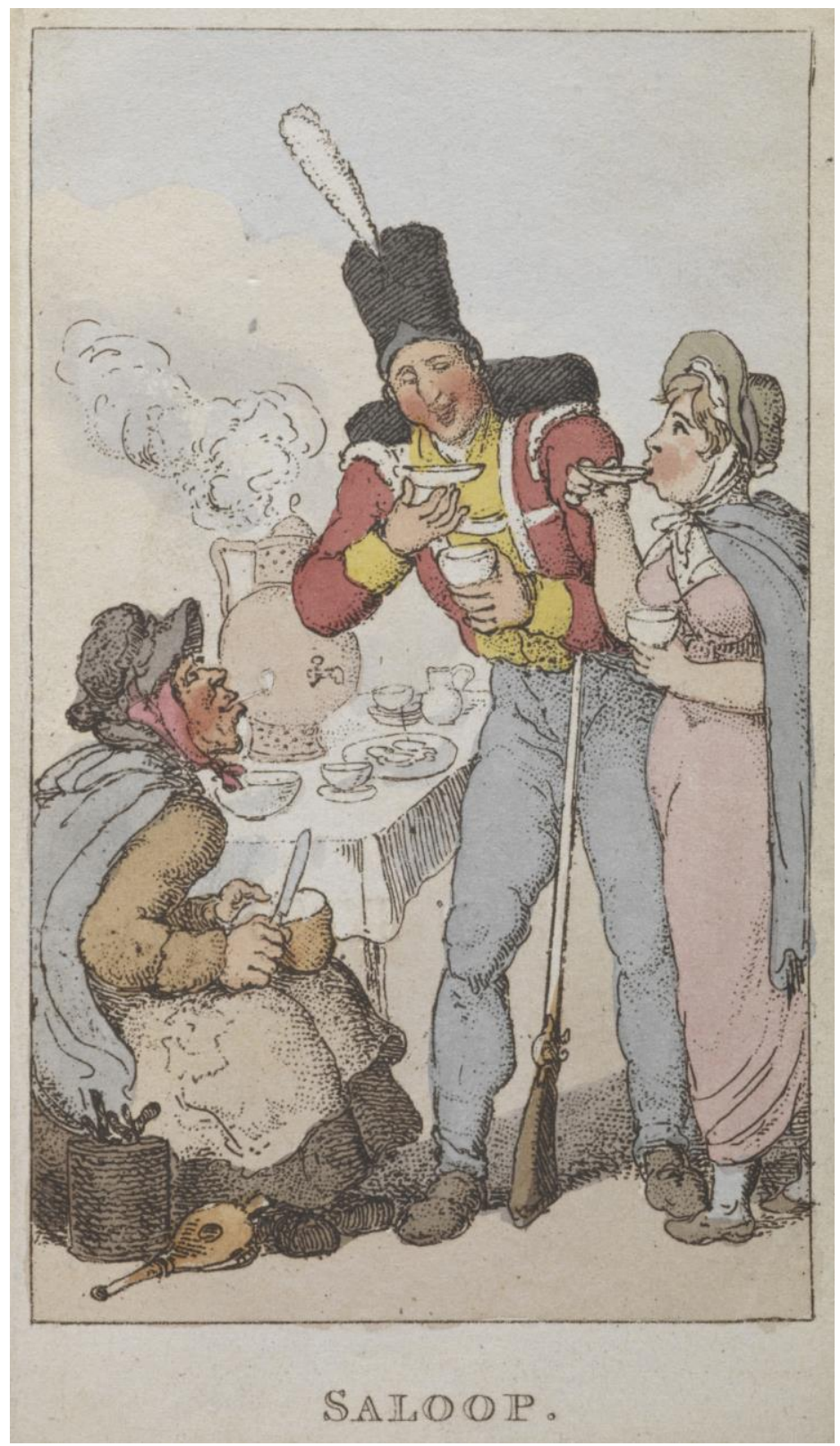

Saloop from Thomas Rowlandson, Rowlandson's Characteristic Sketches of the Lower Orders (London, 1820) 